\title{
ECJ clarifies collecting societies' rights in relation to the cable retransmission right, but leaves questions unanswered
}

\author{
Uradex SCRL v Union Professionnelle de la Radio et de la \\ Télédistribution (RTD), Société intercommunale pour la \\ diffusion de la télévision (Brutélé), European Court of \\ Justice, 1 June 2006, www.curia.eu.int \\ The European Court of Justice (ECJ) has held that \\ Article 9(2) of Directive 93/83 is to be interpreted as \\ meaning that where a collecting society is deemed to \\ be mandated to manage the rights of a copyright owner \\ or holder of related rights who has not transferred the \\ management of his rights to a collecting society that \\ society has the power to exercise that right holder's right \\ to grant or refuse authorization to a cable operator for \\ cable retransmission and, consequently, its mandate is \\ not limited to management of the pecuniary aspects of \\ those rights.

\section{Legal context} \\ Article 9 of Council Directive 93/83 on the coordination \\ of certain rules concerning copyright and rights related to \\ copyright applicable to satellite broadcasting and cable \\ retransmission provides in part that, where a right holder \\ has not transferred the management of his rights to a collecting \\ society, the collecting society which manages rights \\ of the same category shall be deemed to be mandated to \\ manage his rights.
}

\section{Facts}

Uradex is a Belgian collecting society representing performers. It sued RTD and Brutélé, Belgian cable operators, before the Belgian courts for infringement of its related rights because the latter retransmitted, by cable, performances of performers it represents without its authorization. The Cour d'appel of Brussels held that the collecting society does not have the right to exercise the rights of performers or to grant an authoriziation for cable retransmission but is only mandated to manage their rights, ie to collect the remuneration due to performers, for instance for a cable retransmission. In addition, as regards audiovisual performances, the Court held that Uradex cannot exercise the cable retransmission right because Belgian law provides a presumption that the artist assigns his rights to the producer of the audiovisual work (Article 36 of the Belgian Copyright Act). Uradex introduced an appeal before the Cour de Cassation to contest those findings. The Cour de Cassation stayed the proceedings and referred a question for preliminary ruling to the ECJ, asking whether Article 9(2) must be interpreted as meaning that the collecting society managing the rights of performers only has the power to collect the remuneration and not the power to authorize or prevent the right to retransmit performances by cable.

\section{Analysis}


The ECJ disagreed with the Cour d'appel and ruled that Article 9(2) does not limit the scope of the collecting society's management. Its wording does not mean that the collecting society's management only relates to the financial aspects of the rights of performers and excludes the cable retransmission right. Thus the collecting society has the power to authorize or to refuse a cable retransmission. The ECJ added, although it was not obliged to do so as the Cour de Cassation did not ask the question: The Directive does not preclude assignment of the retransmission right. That assignment may be made both on the basis of a contract and by virtue of a legal presumption. Thus, the Directive does not prevent an author, artist, performer or producer from losing, pursuant to a national provision such as Article 36(1) of the Law, his status of 'right holder' of that right within the meaning of Article 9(2) of the Directive, with the consequential severance of all legal links existing under that provision between him and the collecting society (para 24).

\section{Practical significance}

The ECJ's ruling first clarifies the scope of the collecting societies' rights. By holding that collecting societies exercise the right of retransmission rather than only collect remuneration, it interprets Article 9(2) correctly. Indeed, Article 9 is entitled 'Exercise of the cable retransmission right'; nothing in it limits the power of the collecting societies to the financial aspects of the retransmission right only. This interpretation, which keeps within the objective of the norm and the intent of the lawmaker, is to be applauded.

With regard to the second point, as the ECJ rightly points out, Article 9(2) does not prevent the performer from alienating his right of retransmission. Article 36 of the Belgian Copyright Act, which presumes the transfer of the performers' rights to the audiovisual producers, is perfectly valid under Community law. The only condition Article 9(2) imposes is that it belongs to a collecting society. The question is therefore to determine which collecting society is entitled to exercise this right. As the

Advocate General perceives (paragraphs 49 and 50 of his Opinion), there are two possibilities. The first is to consider the rights acquired by producers as the artists and performers' own rights, the relevant collecting society therefore being that of the performers. The second is to deem the rights thereby transferred to the producers as having a nature identical to those of the producers. The relevant society would then be that of the producers. The Advocate General indicates that Article 9(2) does not demand that a single collecting society manages the exclusive cable retransmission right. Thus, in the case of audiovisual performances, at least two collecting societies would be involved and the cable distributors would be obliged to contract with both.

The choice between these two options is an issue for the Belgian courts. The ECJ takes care not to choose one or the other. However, it stresses that, when the original right holder 'loses' his right, all legal links between him and the collecting society are severed. 
If collecting societies representing performers and producers are allowed to manage performers' rights, it complicates the contractual arrangements that need to be put in place to collect the remuneration for the cable retransmission right. The objective of the Community norm was definitely to simplify this mechanism to the maximum. The existence of two, and possibly more, collecting societies with which to deal departs from the norm's aim. In addition, the second option faces a practical and common problem. If a performer has already transferred his right to the performers' society before contracting with the film producer, neither the legal presumption of Article 36 nor the contractual assignment can function: one cannot transfer a right twice. In this case, the collecting society representing the performers should prevail. Besides, if the Belgian courts choose the second option, producers' collecting societies will collect the performers' revenue and there is a high risk that they will not pay it back to the performers. Article 9(2) provides perhaps the strongest argument against the second option. The first sentence states,

Where a right holder has not transferred the management of his rights to a collecting society, the collecting society which manages rights of the same category shall be deemed to be mandated to manage his rights. This seems to mean categorically that the exercise of the right of retransmission of performers who are not members of a collecting society can only be managed by the collecting society which manages the rights of the same category (a producers' collecting society cannot manage the rights of performers since they belong to another category), independently of the fact that those performers have transferred their cable retransmission right to another person (a producer for instance). The Directive implies that the question of the exercise of the right to authorize or prevent the cable retransmission is dissociated from that of the ownership and transfer of this right. The ECJ has left open most practical issues relating to the management of the cable retransmission rights of performers, in particular when a national provision presumes the transfer of this right. The Belgian courts will have to take a position on those issues and in particular on the compatibility between the assignment of rights to a collecting society resulting from membership and the contractual arrangement with producers concluded afterwards.

Estelle Derclaye

University of Nottingham

Alain Strowel

Facultés Universitaires Saint-Louis, Covington \& Burling, Brussels 